\title{
Sensitivity Studies for Propane Oxidative Dehydrogenation to Propylene in Circulating Fluidized Bed
}

\author{
A.H. Fakeeha*, M.A. Soliman and A.A. Ibrahim \\ Chemical Engineering Department, College of Engineering, King Saud University, P.O. Box 800, Riyadh 11421, Saudi Arabia
}

Received 18 September 2004; accepted 25 April 2005

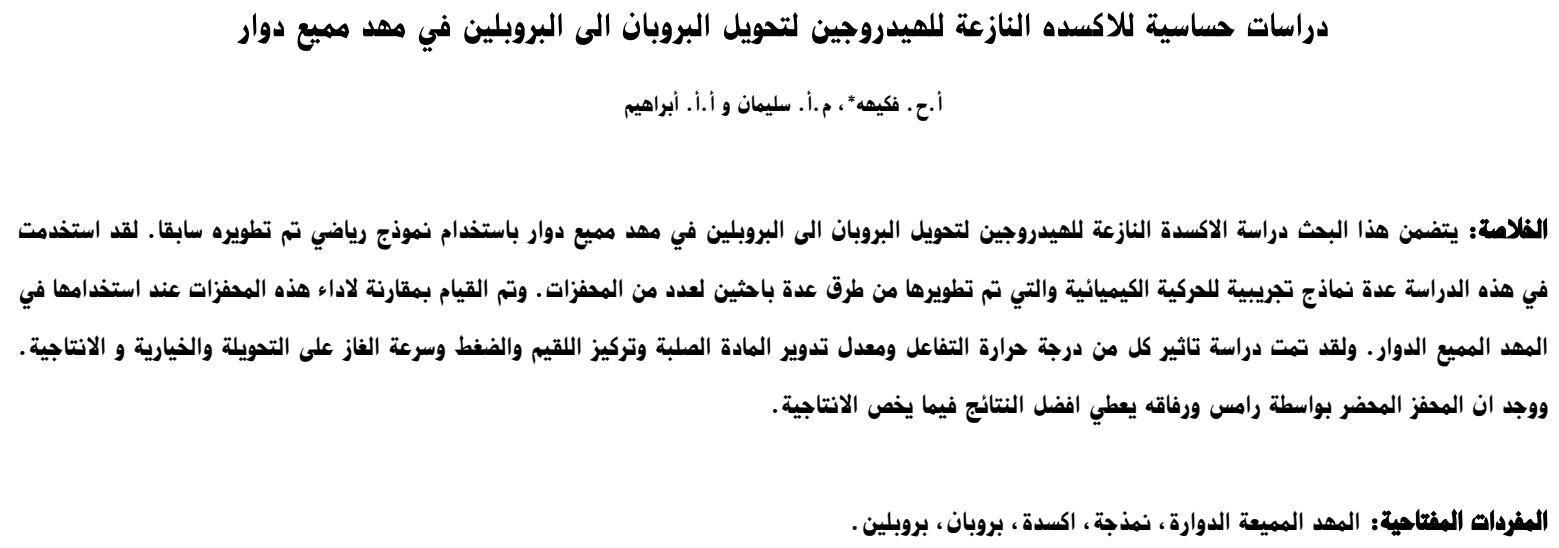

\begin{abstract}
In this paper, simulation and sensitivity studies for propane oxidative dehydrogenation to which were propylene in a circulating fluidized bed is undertaken using a previously developed model. Various experimental kinetics, obtained by several investigators for the reaction using different catalysts, are employed in this study. A comparison is made for the performance of certain catalysts when used in a circulating fluidized bed reactor. The effects of changing reaction temperature, solid circulation rate, feed composition, pressure, and gas superficial velocity on reactant conversion and product selectivity and yields are studied. It was found that the catalyst prepared by Ramos et al. is superior to the others with respect to yield.
\end{abstract}

Keywords: Circulating fluidized bed, Modeling, Oxidation, Propane and propylene

\section{Notation}

$\mathrm{C}_{\mathrm{i}, \mathrm{c}}=$ Concentration of the $\mathrm{i}^{\text {th }}$ species in the core, mole/ $\mathrm{L}$

$\mathrm{C}_{\mathrm{i}, \mathrm{a}}=$ Concentration of the $\mathrm{i}^{\text {th }}$ species in the annulus, mole/ $\mathrm{L}$

$\mathrm{D}_{\mathrm{p}} \quad=$ Mean particle diameter, $\mathrm{m}$

$\mathrm{D}_{\mathrm{t}} \quad=$ Riser diameter, $\mathrm{m}$

$\mathrm{g}=$ Gravitational acceleration constant, $\mathrm{m} / \mathrm{s}^{2}$

$\mathrm{G}_{\mathrm{s}} \quad=$ Overall solids circulation rate, $\mathrm{kg} /\left(\mathrm{m}^{2} \mathrm{~s}\right)$

$\mathrm{k}=$ Proportionality constant in the acceleration zone, $\mathrm{m}^{-1}$

$\mathrm{k}_{\mathrm{g}}=$ Gas mass-transfer coefficient from core to annulus, $\mathrm{m} / \mathrm{s}$

$\mathrm{k}_{\mathrm{c}} \quad=$ Reaction rate constant

$\mathrm{K}=$ Equilibrium constant, $\mathrm{mol} / \mathrm{L}$

$\mathrm{L}_{\mathrm{acc}}=$ Length of the acceleration zone, $\mathrm{m}$

$\mathrm{P} \quad=$ Total pressure, $\mathrm{Pa}$

$\mathrm{r}_{\mathrm{i}} \quad=$ Rate of the $\mathrm{i}^{\text {th }}$ reaction, $\mathrm{mol} /(\mathrm{g} . \mathrm{s})$

$\mathrm{r}_{\mathrm{c}} \quad=$ Core radius, $\mathrm{m}$

*Corresponding author’s e-mail: anishf@ksu.edu.sa 


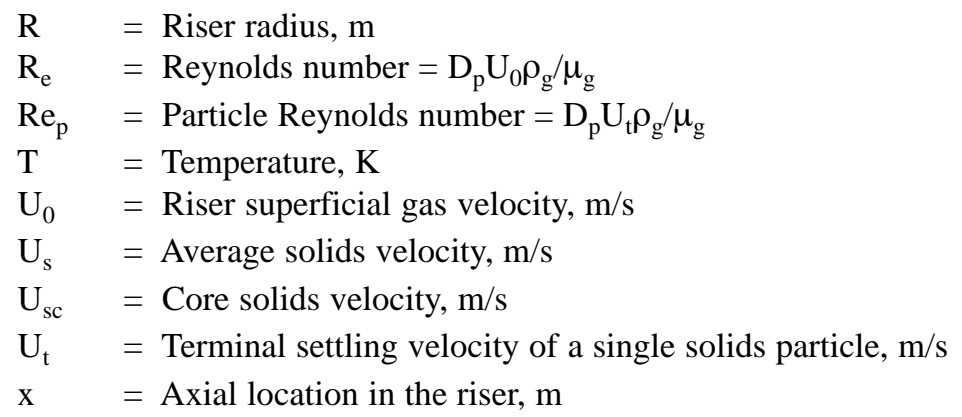

\section{Greek Letters}

$$
\begin{aligned}
& \Gamma=\text { Constant in acceleration zone } \\
& \varepsilon_{\text {ann }}=\text { Annular voidage } \\
& \varepsilon_{\text {avg. }}=\text { Average axial voidage } \\
& \varepsilon_{\mathrm{b}}=\text { Apparent voidage at riser bottom } \\
& \varepsilon_{\mathrm{c}}=\text { Core voidage } \\
& \varepsilon_{\mathrm{mf}}=\text { Voidage at mi nimum fluidization conditions } \\
& \varepsilon_{\infty}=\text { Voidage at the end of the acceleration zone } \\
& \rho_{\mathrm{g}}, \rho_{\mathrm{s}}=\text { Gas and solid particle densities, } \mathrm{kg} / \mathrm{m}^{3}
\end{aligned}
$$

\section{Introduction}

Alkanes such as propane are available in larger quantities than propylene since it is one of the components of natural or associated gas. The lower cost of propane, encourages further research to develop new catalysts and processes for propane utilization to produce many products such as propylene. The reaction can be carried out either in a fixed bed or circulating fluidized bed reactor (CFB), which is shown schematically in Fig. 1.

Several investigators studied oxidation reaction in CFB both theoretically and experimentally. The theoretical simulation studies include the work of Fakeeha et al. (2001) for the ammoxidation of propane to acronitrile, Pugsley et al. (1992) and Fakeeha et al. (2000) for nbutane oxidation to maleic anhydride, Pugsley and Berruti (1996) and Pannek and Mleczko (1998) for oxidative coupling of methane, Pugsley and Malcus (1997) for the partial oxidation of methane to synthesis gas, Patience and Mills (1994) for partial oxidation of propylene to acrolein and Gainetto et al. (1990) for the ammoxidation of propylene into acrylonitrile and toluene to benzonitrile. On the contrary, Golbig and Werther (1997) carried out experimentally the partial oxidation of n-butane to maleic anhydride in CFB.

In this paper simulation and sensitivity studies for propane oxidative dehydrogenation to propylene in CFB reactor will be carried out using three different kinetics based on Mg-V-Sb oxide catalysts (Michaels et al. 1996; Creaser and Anderson, 1996; Ramos et al. 2001) to determine the most suitable catalyst to carry out the reaction in CFB. Sensitivity analysis of the operating conditions such as temperature, superficial velocity, pressure, solid circulation rate as well as propane and oxygen feed compositions will be performed.

\section{Model Development}

The model consists of a couple of differential mass balance equations for each component, one for the mass balance in the core and the other for the mass balance in the

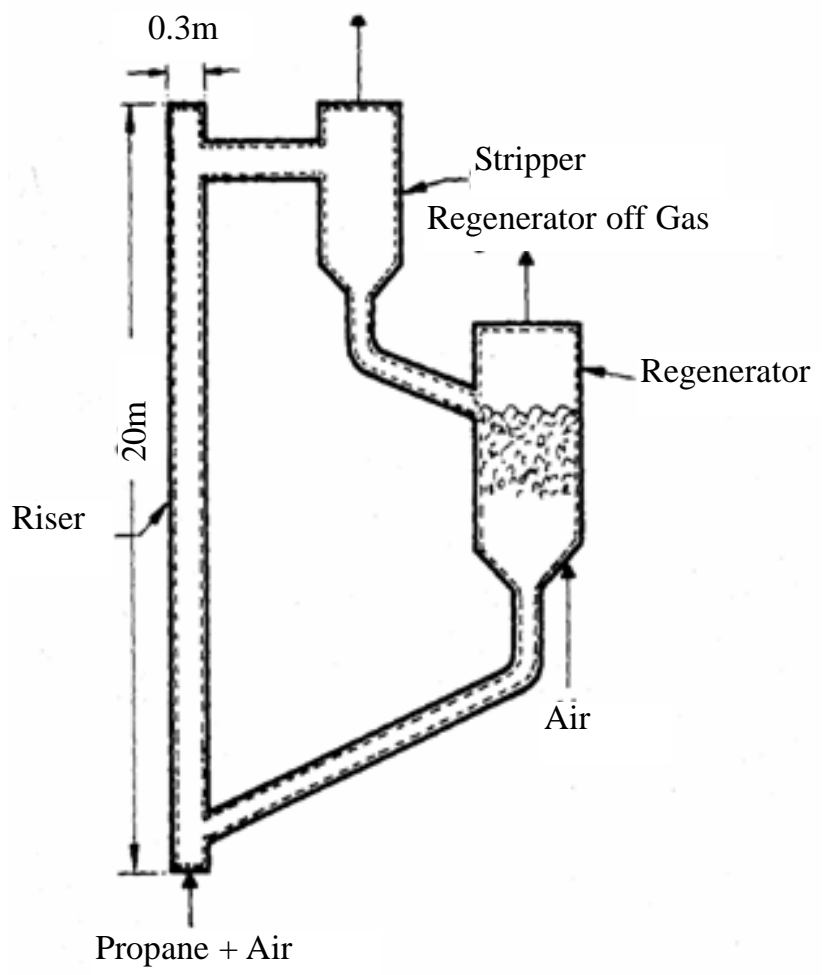

Figure 1. Schematic diagram of a circulating fluidized bed as catalytic reactor 
annulus. This model requires knowledge of the reaction kinetics and the hydrodynamics, therefore the combined models of Berruti and Kalogerakis (1989) and Wong et al. (1992) is used for the description of the hydrodynamics.

Accordingly, the hydrodynamic model equations are:

$\mathrm{U}_{\mathrm{s}}=\mathrm{G}_{\mathrm{s}} /\left[\rho_{\mathrm{s}}\left(1-\varepsilon_{\mathrm{avg}}\right)\right]$

$\varepsilon_{\mathrm{avg}}=\left(\mathrm{U}_{0} \rho_{\mathrm{s}}\right) /\left(2 \mathrm{G}_{\mathrm{s}}+\mathrm{U}_{0} \rho\right)$

$\left(\frac{L_{\text {acc }}}{D_{t}}\right)=7.92 \times 10^{8}\left(D_{t} / D_{p}\right)^{-0.76}$

$$
\left(\rho_{\mathrm{s}} / \rho_{\mathrm{g}}\right)^{-1.21}\left(1+\mathrm{G}_{\mathrm{s}} / \mathrm{U}_{0} \rho_{\mathrm{g}}\right)^{0.28} \mathrm{Re}^{-0.97}
$$

$\varepsilon_{\mathrm{c}}=1-\frac{\mathrm{G}_{\mathrm{s}}+\left[1-\left(\frac{{ }_{\mathrm{C}}^{\mathrm{C}}}{\mathrm{R}}\right)^{2}\right] \rho_{\mathrm{s}}\left(1-\varepsilon_{\mathrm{mf}}\right) \mathrm{U}_{\mathrm{t}}}{\rho_{\mathrm{s}}\left(\frac{{ }_{\mathrm{C}} \mathrm{C}}{\mathrm{R}}\right)^{2}\left[\frac{\mathrm{U}_{\mathrm{O}}}{\varepsilon_{\mathrm{c}}}\left(\frac{\mathrm{R}}{\mathrm{r}_{\mathrm{c}}}\right)^{2}-\mathrm{U}_{\mathrm{t}}\right]}$

$$
\left(\frac{{ }^{\mathrm{r}} \mathrm{c}}{\mathrm{R}}\right)^{2}=\frac{\varepsilon_{\mathrm{av}}-\varepsilon_{\mathrm{mf}}}{\varepsilon_{\mathrm{c}}-\varepsilon_{\mathrm{mf}}}
$$

where the apparent voidage at the riser bottom $\left(\varepsilon_{\mathrm{b}}\right)$ is calculated from a constant $\Gamma$ by solving the quadratic equation

$$
\frac{1-\varepsilon_{b}}{1-\varepsilon_{\infty}}=\frac{U_{s}^{2} k \Gamma}{g}+\frac{1}{(1-\Gamma)}
$$

with:

$$
\varepsilon_{\mathrm{b}}=0.714\left(\mathrm{G}_{\mathrm{s}} / \rho_{\mathrm{s}} \mathrm{U}_{0}\right)^{-0.02528} \mathrm{D}_{\mathrm{t}}^{-0.0794} \mathrm{Re}_{\mathrm{p}}^{-0.12016}
$$

Equation (6), being quadratic, has two roots. We choose the root which is less than one. Theoretical development leading to Eq. (9) requires $\Gamma$ to be a fraction. In Eq. (6), $\mathrm{k}$ is given by:

$\mathrm{k}=-\ln (0.01) / \mathrm{L}_{\mathrm{acc}}$

Finally we obtain the average voidage in the acceleration zone as

$\varepsilon_{\text {avg }}=1-\frac{\left(1-\varepsilon_{\infty}\right)}{1-\Gamma \exp (-\mathrm{kx})}$

The CFB is assumed isothermal and reactions occur in core and annular regions. The gas input to the annulus is due solely to cross flow from the core. The following parameters and operating conditions are considered in the study which are catalyst properties:
$\mathrm{D}_{\mathrm{p}}=75 \mu \mathrm{m} ; \rho_{\mathrm{s}}=1500 \mathrm{~kg} / \mathrm{m}^{3} ; \varepsilon_{\mathrm{mf}}=0.5 ; \mathrm{U}_{\mathrm{t}}=2 \mathrm{~m} / \mathrm{s}$

The simulation reactions require solution of two mass balance equations for each species:

\section{A Core Region Mass Balance}

$-\frac{\delta}{\delta \mathrm{x}}\left(\mathrm{U}_{\mathrm{o}} \mathrm{C}_{\mathrm{i}, \mathrm{c}}\right)+\rho_{\mathrm{s}}\left(1-\varepsilon_{\mathrm{c}}\right) \mathrm{r}_{\mathrm{i}}-\frac{2 \mathrm{k}_{\mathrm{g}}}{\mathrm{r}_{\mathrm{c}}}\left(\mathrm{C}_{\mathrm{i}, \mathrm{c}}-\mathrm{C}_{\mathrm{i}, \mathrm{a}}\right)=0$

\section{B. Annular Region Mass Balance}

$\rho_{\mathrm{s}}\left(1-\varepsilon_{\text {ann }}\right) \mathrm{r}_{\mathrm{i}}+\frac{2 \mathrm{k}_{\mathrm{g}} \mathrm{r}_{\mathrm{c}}}{\mathrm{R}^{2}-\mathrm{r}_{\mathrm{c}}^{2}}\left(\mathrm{C}_{\mathrm{i}, \mathrm{c}}-\mathrm{C}_{\mathrm{i}, \mathrm{a}}\right)=0$

Here the annular voidage, $\varepsilon_{\text {ann }}$ is assumed to be equal to the voidage at minimum fluidization conditions, $\varepsilon_{\mathrm{mf}}$. The $\mathrm{k}_{\mathrm{g}}$ value is in the range of $0.015-0.094 \mathrm{~m} / \mathrm{s}$ as used by Pugsley et al. (1992).

\section{Numerical Algorithm}

The height of the CFB riser $(20 \mathrm{~m})$ is divided into elements of a length of $0.2 \mathrm{~m}$. Testing the base-case with smaller elements length does not improve the accuracy of the simulation results. At each step, the hydrodynamic model is first solved to determine the length of acceleration zone, axial voidage profile, core porosity and core radius of elements. The concentration gradient $\delta c / \delta x$ is discretized in the spatial direction and a forward implicit finite difference is used to solve the mass balance Eqs. (10) and (11). Since there are variations in gas volume due to the reaction at each element, the increase of gas velocity is determined and the hydrodynamic model is solved at the end of each element.

The system of non-linear algebraic equations resulting from discretization is difficult to solve. To provide a good initial guess for the solution of the non-linear system of equations the nonlinear kinetics is linearized around the inlet conditions and the system of approximate linear equations is solved for every step in the spatial direction. Then the system of non-linear algebraic equations are solved for the concentrations of components in the annulus and core regions at each step using the solution obtained from the linearized model as initial guess. Having obtained the concentration of different components of reactants and axial conversion, selectivity and yield of products are calculated.

\section{Kinetics of Oxidative Dehydrogenation of Propane to Propylene}

Many investigators studied the kinetics and mechanism of oxidative dehydrogenation of propane to propylene on different catalysts (Ramos, et al. 2001; Grabowski et al. 2003; Creaser et al. 2000; Chen et al. 2000; Barsan and Thyrion, 2003). In this paper the comparison of the per- 
formance of three fore mentioned catalysts in oxidation of propane based on their kinetics will be performed. Michaels et al. (1996) studied the kinetics and mechanism of propane oxidation on $\mathrm{Mg}_{2} \mathrm{~V}_{2} \mathrm{SbO}_{\mathrm{x}}$. The temperature range used was 723-803 $\mathrm{K}$. The network of reaction is shown in Fig. 2. This catalyst will be called $M$ catalyst in the subsequent work. It is noticed that the oxidative dehydrogenation and deep oxidation of the hydrocarbon occur by two distinctly different mechanisms.

(1) Mars-Van Krevelen mechanism

$\mathrm{C}_{3} \mathrm{H}_{8}+\sigma_{\mathrm{HC}} \Leftrightarrow \mathrm{C}_{3} \mathrm{H}_{6}$ (ads) fast, reversible

$\mathrm{C}_{3} \mathrm{H}_{8}$ (ads) $+\mathrm{O}_{\mathrm{o}} \rightarrow \mathrm{C}_{3} \mathrm{H}_{6}+$ Vo rate-determining

$\mathrm{O}_{2}+2 \mathrm{Vo} \quad \rightarrow 2 \mathrm{Oo}$ fast

where: ads denotes an adsorbed species, $\sigma_{\mathrm{HC}}$ is hydrocarbon adsorption site, $\mathrm{O}_{\mathrm{o}}$ and $\mathrm{Vo}=$ are lattice oxygen and lattice, oxygen vacancy, respectively.

$\rightarrow$ is irreversible, $\Leftrightarrow$ is reversible and equilibrium, $\mathrm{CO}_{\mathrm{x}}$ is carbon oxides

(2) Langmuir-Hinshelwood mechanism

$$
\begin{array}{lll}
\mathrm{C}_{3} \mathrm{H}_{8}+\sigma_{\mathrm{HC}} & \Leftrightarrow \mathrm{C}_{3} \mathrm{H}_{8} \text { (ads) } & \text { fast,reversible } \\
\mathrm{O}_{2}+2 \sigma_{\mathrm{o}} & \Leftrightarrow 2 \mathrm{O}(\text { ads }) & \text { fast, reversible } \\
\mathrm{C}_{3} \mathrm{H}_{8} \text { (ads) }+\mathrm{O} \text { (ads) } \rightarrow \mathrm{CO}_{\mathrm{x}} & \text { rate-determining }
\end{array}
$$

where $\sigma_{0}$ is oxygen adsorption site.

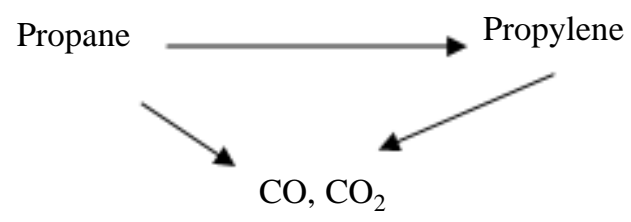

\section{Figure 2. Reaction network for propane oxidation (Michaels et al. 1996)}

Rate expressions for oxidative dehydrogenation and deep oxidation of propane are given next.

$$
\begin{gathered}
\mathrm{r}_{\text {propane }}=\frac{\mathrm{k}_{\mathrm{pro}} \mathrm{X}_{\mathrm{pro}}}{1+\mathrm{K}_{\mathrm{pro}} \mathrm{X}_{\mathrm{pro}}} \\
\mathrm{r}_{\mathrm{CO}}=\frac{\mathrm{k}_{\mathrm{CO}} \mathrm{X}_{\mathrm{pro}} \mathrm{X}_{\mathrm{O}_{2}}^{1 / 2}}{1+\mathrm{K}_{\mathrm{pro}} \mathrm{X}_{\mathrm{pro}}} \\
\mathrm{r}_{\mathrm{CO}_{2}}=\frac{\mathrm{k}_{\mathrm{CO}_{2}} \mathrm{X}_{\mathrm{pro}} \mathrm{X}_{\mathrm{O}_{2}}^{1 / 2}}{1+\mathrm{K}_{\mathrm{pro}} \mathrm{X}_{\mathrm{pro}}}
\end{gathered}
$$

where: $\mathrm{r}=$ reaction rate, $\mathrm{k}=$ rate constant, $\mathrm{x}=$ mole fraction, $\mathrm{K}=$ adsorption equilibrium constant and
$\mathrm{K}_{\text {pro }}($ adsorption $)=\exp \left(\frac{\Delta \mathrm{S}_{\text {ads }}}{\mathrm{R}}\right) \exp \left(\frac{-\Delta \mathrm{H}_{\mathrm{ads}}}{\mathrm{RT}}\right)$

\begin{tabular}{|c|c|c|c|c|}
\hline & \multicolumn{4}{|c|}{ Temperature, ${ }^{0} \mathrm{C}$} \\
\hline & 450 & 474 & 500 & 530 \\
\hline $10^{8} \times \mathrm{k}_{\text {propane }}(\mathrm{mol} / \mathrm{s})$ & 78 & 173.3 & 286.7 & 438.3 \\
\hline $10^{8} \times \mathrm{k}_{\mathrm{CO}}(\mathrm{mol} / \mathrm{s})$ & 113.3 & 181.7 & 245 & 435 \\
\hline $10^{4} \times \mathrm{k}_{\mathrm{CO} 2}(\mathrm{~mol} / \mathrm{s})$ & 250 & 390 & 500 & 796.7 \\
\hline $\mathrm{K}_{\text {pro }}$ & 2.58 & 3.55 & 3.27 & 2.37 \\
\hline $\begin{array}{l}\text { E (activation energ } \\
\text { oxidative dehydrogen }\end{array}$ & $\begin{array}{l}\text { for } \\
\text { tion }\end{array}$ & artial & $103.3 \mathrm{~kJ}$ & \\
\hline $\begin{array}{l}\text { E (activation ener } \\
\text { oxidation CO }\end{array}$ & y) for & d eep & $79.1 \mathrm{~kJ} / \mathrm{r}$ & \\
\hline $\begin{array}{l}\mathrm{E} \text { (activation ener } \\
\text { oxidation } \mathrm{CO}_{2}\end{array}$ & y) for & d eep & $65.3 \mathrm{~kJ} / \mathrm{r}$ & \\
\hline Enthalpy & & & $-6.3 \mathrm{~kJ} / \mathrm{n}$ & \\
\hline Entropy & & & 0.1 e.u. & \\
\hline
\end{tabular}

where pro stands for propane and the entropy of adsorption value are 0.1 e.u. and $-6.3 \mathrm{~kJ} / \mathrm{mol}$ respectively as shown in Table 1.

\section{Table 1. Kinetic model parameters (Michaels et al. 1996)}

Creaser and Anderson (1996) studied the kinetics of propane oxidation on V-Mg-O catalyst with $60 \mathrm{wt} \% \mathrm{MgO}$ and 40 wt $\% \mathrm{~V}_{2} \mathrm{O}_{5}$. The temperature range used was 783$823 \mathrm{~K}$. This catalyst will be called $\mathrm{C}$ catalyst in the subsequent work. The mechanism of the reaction is as follows.

1) Propane reacts directly with surface oxygen according to

$\mathrm{C}_{3} \mathrm{H}_{8}+\mathrm{OO} \longrightarrow \mathrm{C}_{3} \mathrm{H}_{6}+\mathrm{H}_{2} \mathrm{O}+\mathrm{C}$

2) The absorbed propylene reacts further with surface oxygen to give carbon oxides.

$\mathrm{C}_{3} \mathrm{H}_{6}+3(\mathrm{n}+1) \mathrm{QO} \longrightarrow 3 \mathrm{CO}_{\mathrm{n}}+3 \mathrm{H}_{2} \mathrm{O}+(3 \mathrm{n}+4) \mathrm{a}$

where $\mathrm{n}=1$ or $2, \square \mathrm{O}=$ surface oxygen site, $\square=$ free surface site.

The rate equations derived take the form

$\mathrm{r}_{1}=\mathrm{k}_{1} \mathrm{P}_{\mathrm{C}_{3} \mathrm{H}_{8}} \theta_{0}$

$\mathrm{r}_{2}=\mathrm{k}_{2} \theta_{\mathrm{C}_{3} \mathrm{H}_{6}} \theta_{0}$

where the fractional cove rages $\theta_{0}, \theta_{\mathrm{C}_{3} \mathrm{H}_{6}}$ and the adsorption equilibrium constant for oxygen are given below respectively; the kinetic parameters are given in Table 2.

$\theta_{0}=\frac{\sqrt{\mathrm{K}_{\mathrm{O} 2} \mathrm{P}_{\mathrm{O} 2}}}{1+\sqrt{\mathrm{K}_{\mathrm{O} 2} \mathrm{P}_{\mathrm{O} 2}}}$ 


$$
\begin{aligned}
& \theta_{\mathrm{C}_{3} \mathrm{H}_{6}}=\frac{\mathrm{K}_{\mathrm{C}_{3} \mathrm{H} 6} \mathrm{P}_{\mathrm{C}^{3} 6}}{1+\mathrm{K}_{\mathrm{C}_{3} \mathrm{H} 6} \mathrm{P}_{\mathrm{C}_{3} \mathrm{H} 6}} \\
& \mathrm{~K}_{\mathrm{O} 2}=\mathrm{K}_{\mathrm{O} 2}^{0} \exp \left[\frac{-\Delta \mathrm{H}_{\mathrm{O} 2}}{\mathrm{R}}\left(\frac{1}{\mathrm{~T}}-\frac{1}{\mathrm{~T}^{\mathrm{m}}}\right)\right]
\end{aligned}
$$

where :

$\mathrm{T}^{\mathrm{m}}=$ reference temperature,

$\mathrm{r}=$ reaction rate,

$\mathrm{k}=$ rate constant,

$\mathrm{K}=$ adsorption equilibrium constant at temperature $\mathrm{T}$,

$\mathrm{K}^{0}=$ adsorption equilibrium constant at temperature $\mathrm{T}^{\mathrm{m}}$.

Table 2. Kinetic parameters of Creaser and

\begin{tabular}{|c|c|c|c|}
\hline Parameter & Value & $\begin{array}{c}\text { Confidence } \\
\text { interval } \\
(95 \%)\end{array}$ & Units \\
\hline$k_{10}$ & $2.50 \times 10^{-4}$ & $\pm 1.42 \times 10^{-5}$ & 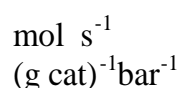 \\
\hline$k_{20}$ & $2.35 \times 10^{-5}$ & $\pm 1.37 \times 10^{-5}$ & $\begin{array}{l}\mathrm{mol} \mathrm{s}^{-1} \\
(\mathrm{~g} \mathrm{cat})^{-1}\end{array}$ \\
\hline$E_{a 1}$ & $1.23 \times 10^{1}$ & $\pm 1.25 \times 10^{2}$ & $\mathrm{~kJ} \mathrm{~mol}^{-1}$ \\
\hline$E_{a 2}$ & $2.34 \times 10^{1}$ & $\pm 1.31 \times 10^{2}$ & $\mathrm{~kJ} \mathrm{~mol}^{-1}$ \\
\hline$\Delta H_{C_{3} H_{6}}$ & $-2.29 \times 10^{2}$ & $\pm 1.53 \times 10^{2}$ & $\mathrm{~kJ} \mathrm{~mol}^{-1}$ \\
\hline$\Delta H_{\mathrm{O}_{2}}$ & $3.56 \times 10^{2}$ & $\pm 3.59 \times 10^{2}$ & $\mathrm{~kJ} \mathrm{~mol}^{-1}$ \\
\hline$K_{O_{2}}^{0}$ & $3.58 \times 10^{0}$ & $\pm 7.18 \times 10^{0}$ & \\
\hline
\end{tabular}
Anderson (1996)

Ramos et al. (2001) studied the kinetics of propane oxidation on V-Mg-O with $24 \mathrm{wt} \% \mathrm{~V}_{2} \mathrm{O}_{5}$ and $76 \mathrm{wt} \% \mathrm{MgO}$. The range of temperature was $450-550 \mathrm{~K}$. This catalyst will be called $\mathrm{R}$ catalyst in the subsequent work. The reaction scheme suggested is given in Fig. 3 below:

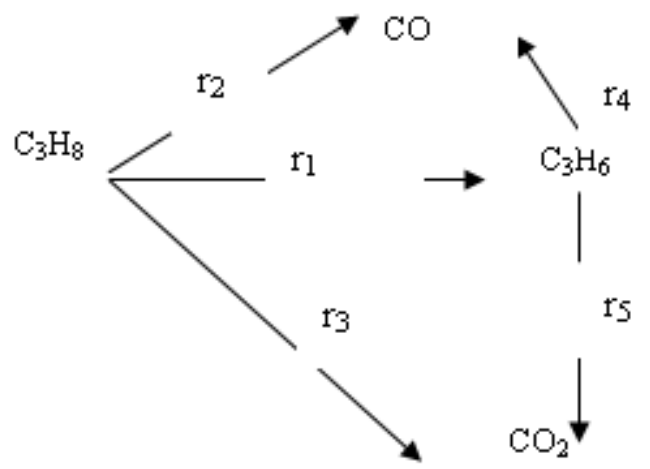

Figure 3. Reaction network for propane oxidation (Ramos et al. 2001)

The power law model takes the form:

$\mathrm{r}_{\mathrm{i}}=\mathrm{k}_{\mathrm{i}} \mathrm{P}_{\mathrm{O}_{2}}^{\mathrm{a}} \quad \mathrm{P}_{\mathrm{HC}}^{\mathrm{b}} \quad \mathrm{i}=1,2,5$. $\mathrm{k}_{\mathrm{i}}=\mathrm{k}_{\mathrm{i} 0} \exp \frac{-\mathrm{E}}{\mathrm{R}}\left(\frac{1}{\mathrm{~T}}-\frac{1}{\mathrm{~T}_{\mathrm{m}}}\right)$

where: $\mathrm{T}_{\mathrm{m}}=773.15 \mathrm{~K}, \mathrm{r}$ = reaction rate, $\mathrm{k}_{0}=$ rate constant at reference temperature.

The kinetic parameters for Ramos et al. (2001) are presented in Table 3, where: $\mathrm{E}_{\mathrm{a}}=$ activation energy, $\mathrm{RC}=$ regression coefficient.

The reactor model and its numerical solutions used in this work were presented by Fakeeha et al. (2000, 2001) before.

\section{Results and Discussion}

The base case parameters used in this study are shown in Table 4. The results for the base case for different catalysts at the end of the riser height of $20 \mathrm{~m}$ are shown in Table 5. This case will be used in the sensitivity analysis as a basis for comparison.

Changing one parameter of the base case is performed each time while keeping the other parameters constant in order to carry out the sensitivity study. The effects of changing temperature, solid circulation rate, feed composition, pressure and superficial gas velocity are studied. The variation of the mass transfer coefficient $\mathrm{k}_{\mathrm{g}}$ in the range of $0.015-0.094 \mathrm{~ms}^{-1}$ was found to have a very slight effect on conversion.

\subsection{Effect of Temperature}

For catalysts $\mathrm{C}$ and $\mathrm{M}$, as temperature increases, the conversion increases linearly; while using catalyst R, the conversion along the riser increased initially at a sharp rate, then the rate of conversion increase becomes slow. However R catalyst gives the highest conversion, e.g. at a temperature of $823 \mathrm{~K}$, the conversion with $\mathrm{R}$ catalyst could reach about $12 \%$, C catalyst reaches about $5.5 \%$ and the $\mathrm{M}$ catalyst reaches only $1.0 \%$ (Fig. 4). On the other hand, the selectivity with $\mathrm{M}$ catalyst is the highest and constant along the riser length, attaining values in the range of $97-98 \%$ at highest temperature. For catalyst C, the activation energy for the product $\mathrm{k}_{2} \mathrm{~K}_{\mathrm{C} 3 \mathrm{H} 6}$, for $\mathrm{CO}$ and $\mathrm{CO}_{2}$ formation is lower than that for $\mathrm{k}_{1}$ for propylene formation, thus, we obtain higher selectivity for propylene at higher temperature (Fig. 5). While for catalyst R, the changes of selectivity in the first $0-1 \mathrm{~m}$ length of the riser are too small to be significant. Moreover, the activation energies for the formation of $\mathrm{CO}$ and $\mathrm{CO}_{2}$ from propylene $\left(r_{4}, r_{5}\right)$ are higher than that for propylene formation $\left(r_{1}\right)$. Thus we obtain lower selectivity for propylene at higher temperature. In general the $\mathrm{R}$ catalyst gives the highest yield among the catalysts used due to its higher values of conversion and selectivity.

\subsection{Effect of Solid Circulation Rate}

As solid circulation rate increases, conversion increases for all catalysts due to exposure to more catalyst. The increase in conversion has similar trend as that of the tem- 
Table 3. Kinetic parameters of (Ramos et al. 2001)

$\begin{array}{cccccc}\begin{array}{c}\text { Reaction } \\ \text { rates }\end{array} & \begin{array}{c}k_{i 0} \times 10^{6} \\ \left(\mathrm{~mol} / \mathrm{g} . s . b a \mathrm{r}^{\mathrm{a}+\mathrm{b}}\right)\end{array} & \begin{array}{c}E_{a} \\ (\mathrm{~kJ} / \mathrm{mol})\end{array} & \mathrm{a} & \mathrm{b} & \mathrm{RC} \\ r_{1} & 2.30 \pm 0.11 & 157 \pm 5 & 0.05 \pm 0.04 & 1.11 \pm 0.06 & 0.987 \\ r_{2} & 0.51 \pm 0.12 & 151 \pm 23 & 0.55 \pm 0.33 & 1.13 \pm 0.28 & 0.973 \\ r_{3} & 1.27 \pm 0.13 & 97.5 \pm 11 & 0.63 \pm 0.19 & 1.03 \pm 0.14 & 0.962 \\ r_{4} & 6.23 \pm 0.49 & 241 \pm 13 & 0.27 \pm 0.04 & 1.27 \pm 0.11 & 0.980 \\ r_{5} & 11.8 \pm 0.48 & 202 \pm 6.7 & 0.21 \pm 0.02 & 1.14 \pm 0.06 & 0.985\end{array}$

Table 4. The base case feed condition

\begin{tabular}{lc}
\multicolumn{1}{c}{ Parameters } & Values \\
Pressure, atm & 1.0 \\
Mass transfer coefficient, $\mathrm{k}_{g} \mathrm{~m} \mathrm{~s}^{-1}$ & 0.017 \\
Temperature, $\mathrm{K}$ & 783.0 \\
Superficial gas velocity, $\mathrm{U}_{0}, \mathrm{~m} \mathrm{~s}^{-1}$ & 2.0 \\
Riser length, $\mathrm{m}$ & 20.0 \\
Riser diameter, $\mathrm{m}$ & 0.3 \\
Solid circulation rate, G, $\mathrm{kg} \mathrm{m}^{-2} \mathrm{~s}^{-1}$ & 400.0 \\
$\quad \quad$ Feed composition (\%) & \\
$\mathrm{C}_{3} \mathrm{H}_{8} \quad$ & 5.0 \\
$\mathrm{O}_{2}$ & 2.0
\end{tabular}

Table 5. The results for the simulation of the base case at the exit of the reactor

$\begin{array}{cccc}\text { Catalyst } & \%_{\mathrm{C}_{3} \mathrm{H}_{6}} & \% \mathrm{C}_{3} \mathrm{H}_{6} & \%_{\mathrm{C}_{3} \mathrm{H}_{6}} \\ \text { Type } & \text { Conversion } & \text { Selectivity } & \text { Yield } \\ \mathrm{C} & 1.46 & 35.35 & 0.52 \\ \mathrm{M} & 0.73 & 98.23 & 0.72 \\ \mathrm{R} & 4.57 & 73.25 & 3.35\end{array}$

perature. The results are shown in Figs. 6 and 7, for conversion and selectivity respectively. The highest conversion obtained for catalyst $\mathrm{R}$ is $5.5 \%$ at $783^{\circ} \mathrm{K}$.

For $\mathrm{M}$ and $\mathrm{C}$ catalysts selectivity increase is very slight and nearly constant with increase of solid circulation rate. The selectivity of propylene did not change apparently because the contribution of the deep oxidation of propylene is small due to the lower conversion of propane to propylene. However for $\mathrm{R}$ it decreases substantially for solid circulation rate. The yield for $\mathrm{M}$ and $\mathrm{R}$ catalysts increases with increase in circulation rate. For the $\mathrm{C}$ catalyst, the yield increases up to $600 \mathrm{~kg} / \mathrm{m}^{2} \mathrm{~s}$ but then decreases at $800 \mathrm{~kg} / \mathrm{m}^{2} \mathrm{~s}$.

\subsection{Effect of Feed Composition}

For $\mathrm{M}$ and $\mathrm{C}$ catalysts, the increase in propane mole fraction does not affect the conversion, because the reac- tion is first order with respect to propane. For R catalyst, as propane mole fraction increases, conversion increases slightly because of propane partial pressure in the kinetic expression is having an exponent of 1.11. For all catalysts, there is no change in selectivity due to changes in propane mole fraction. The non-variance of selectivity on propane mole fraction indicates the same order of dependence on propane mole fraction for propylene, $\mathrm{CO}$ and $\mathrm{CO}_{2}$ formation. The selectivity for $\mathrm{R}$ and $\mathrm{C}$ catalysts decreases substantially along the riser length. The yield for $\mathrm{M}$ catalyst increases slightly and that for C catalysts is not affected by propane mole fraction as may be inferred from Figs. 8 and 9, since there are no appreciable changes in their selectivities and conversions. While for $\mathrm{R}$ catalyst the yield also increases slightly with the increase in mole fraction.

For C and R catalysts in Fig. 10, conversion increases a little with oxygen mole fraction while for $\mathrm{M}$ catalyst conversion does not change because the propane rate of reaction to propylene does not depend on the oxygen mole fraction. All catalysts show a decrease in selectivity with the increase in oxygen mole fraction due to formation of carbon oxides as shown in Fig. 11. The yield for M catalyst is not affected by the increase in oxygen mole fraction but those for $\mathrm{C}$ and $\mathrm{R}$ catalysts increase.

\subsection{Effect of Pressure and Superficial Velocity}

All catalysts show increase in conversion with increase in pressure as depicted in Fig. 12. However, the increase for $\mathrm{M}$ catalyst is fairly small. Selectivity to propylene decreases with increase in pressure due to the formation of carbon oxides as shown in Fig. 13. In all cases the yield increases with the increase in pressure, while $\mathrm{M}$ catalyst gives small increase.

When the superficial velocity increases, conversion decreases in all cases due to lower residence time. For $\mathrm{M}$ catalyst, as velocity increases, selectivity decreases. For C and R catalysts, the selectivity initially decreases with the increase in velocity, but after a short distance along the riser it increases with increase in velocity. In all cases the yield decreases with increase in velocity. 
The Journal of Engineering Research Vol.3, No. 1 (2006) 19-30
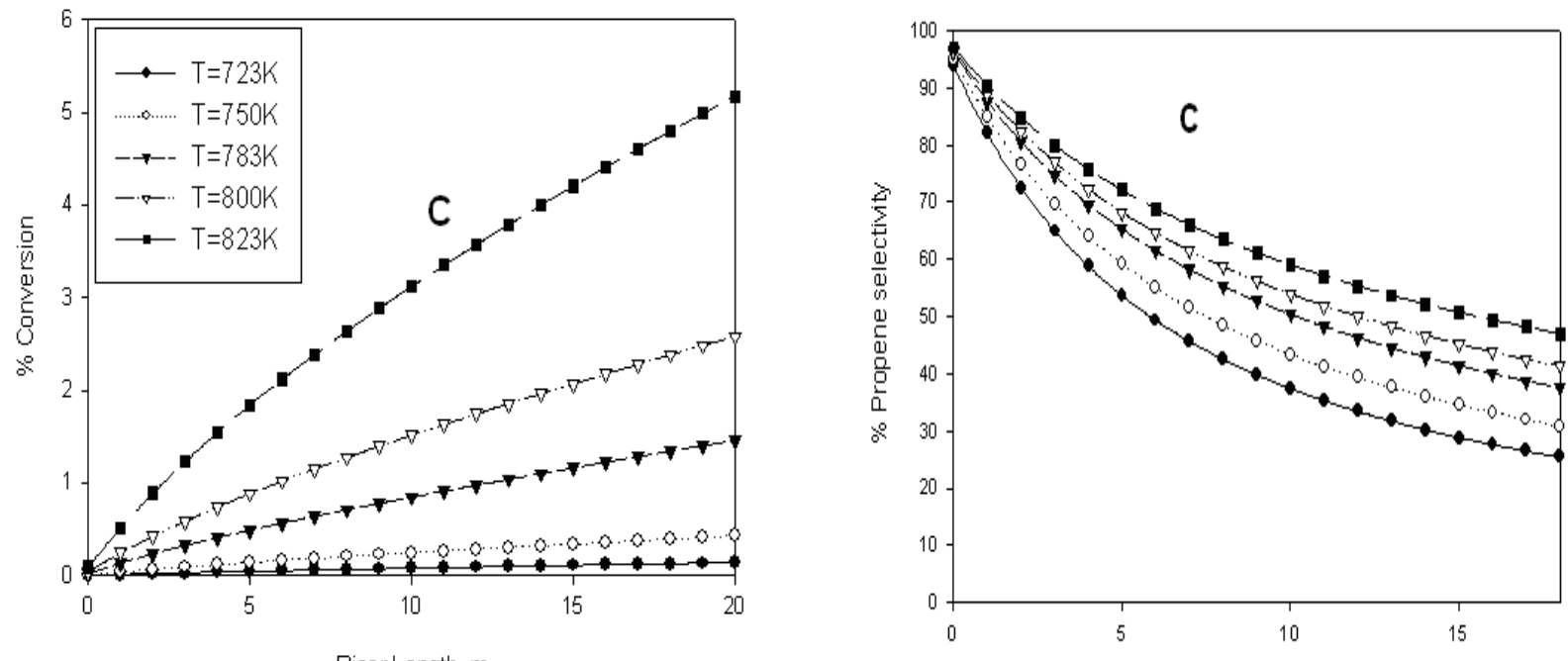

Riser Length, $m$
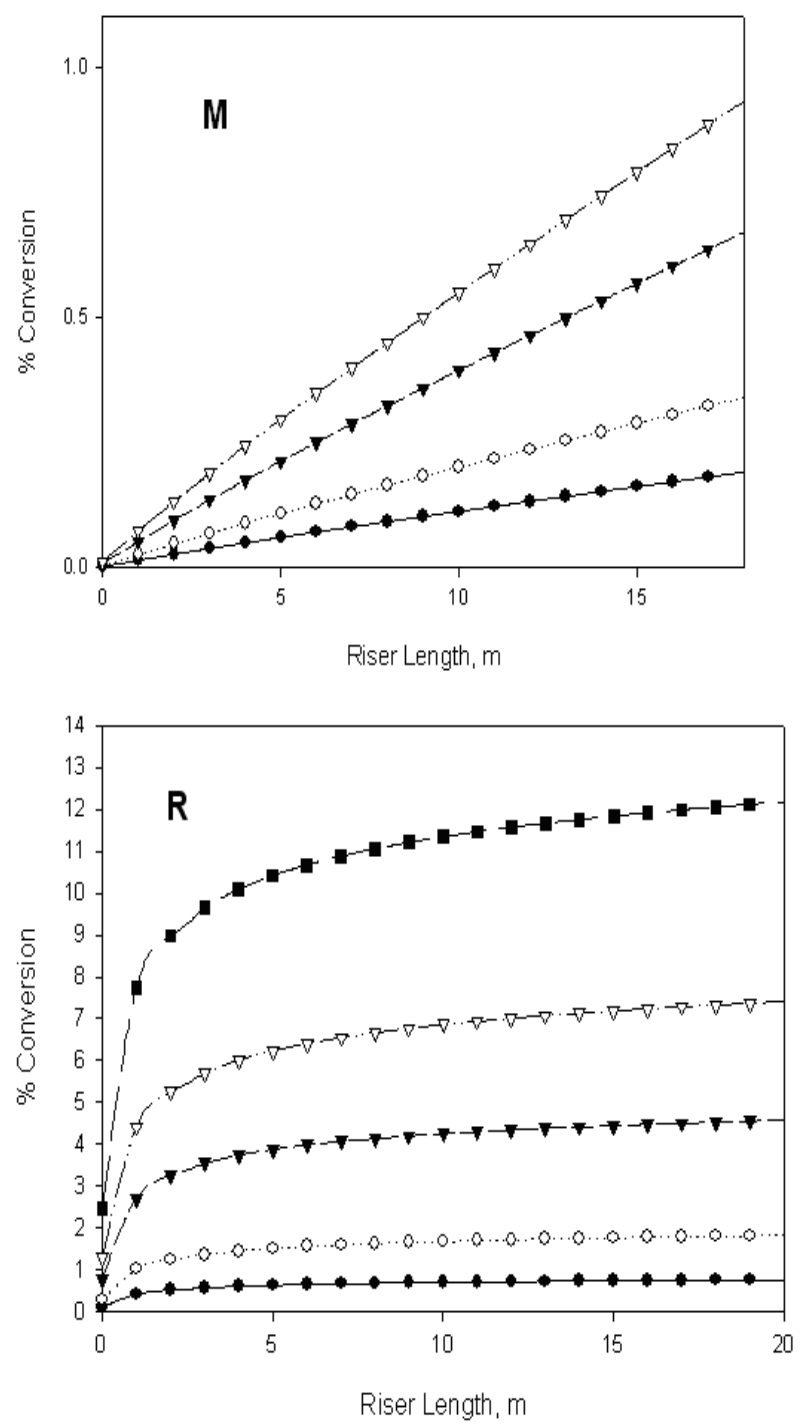

Figure 4. Effect of temperature on propane conversion

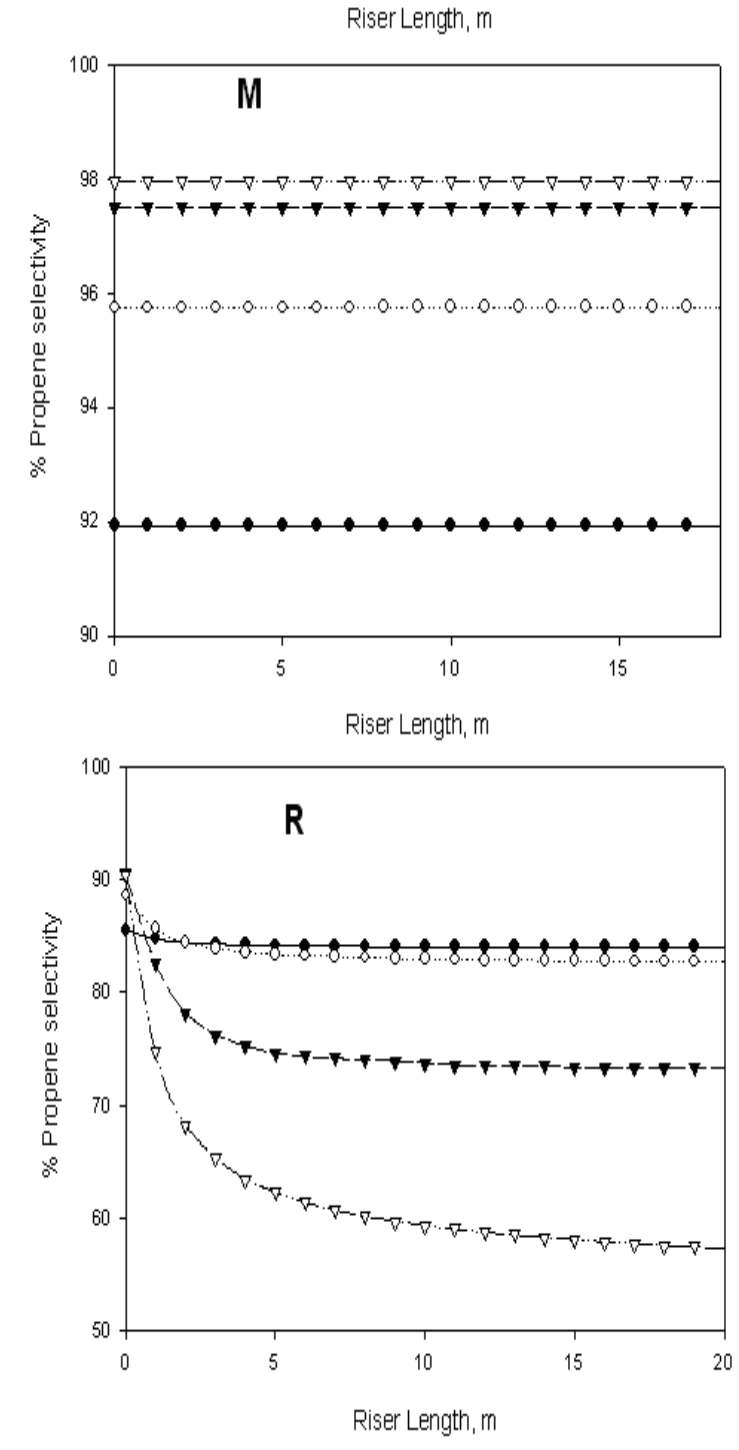

Figure 5. Effect of temperature on propylene selectivity 
The Journal of Engineering Research Vol.3, No. 1 (2006) 19-30

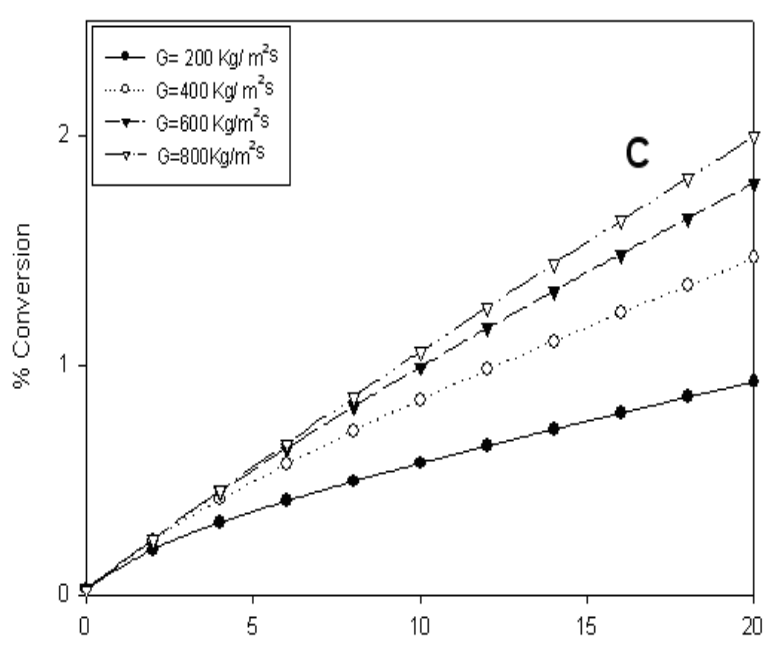

Riser Length, $m$
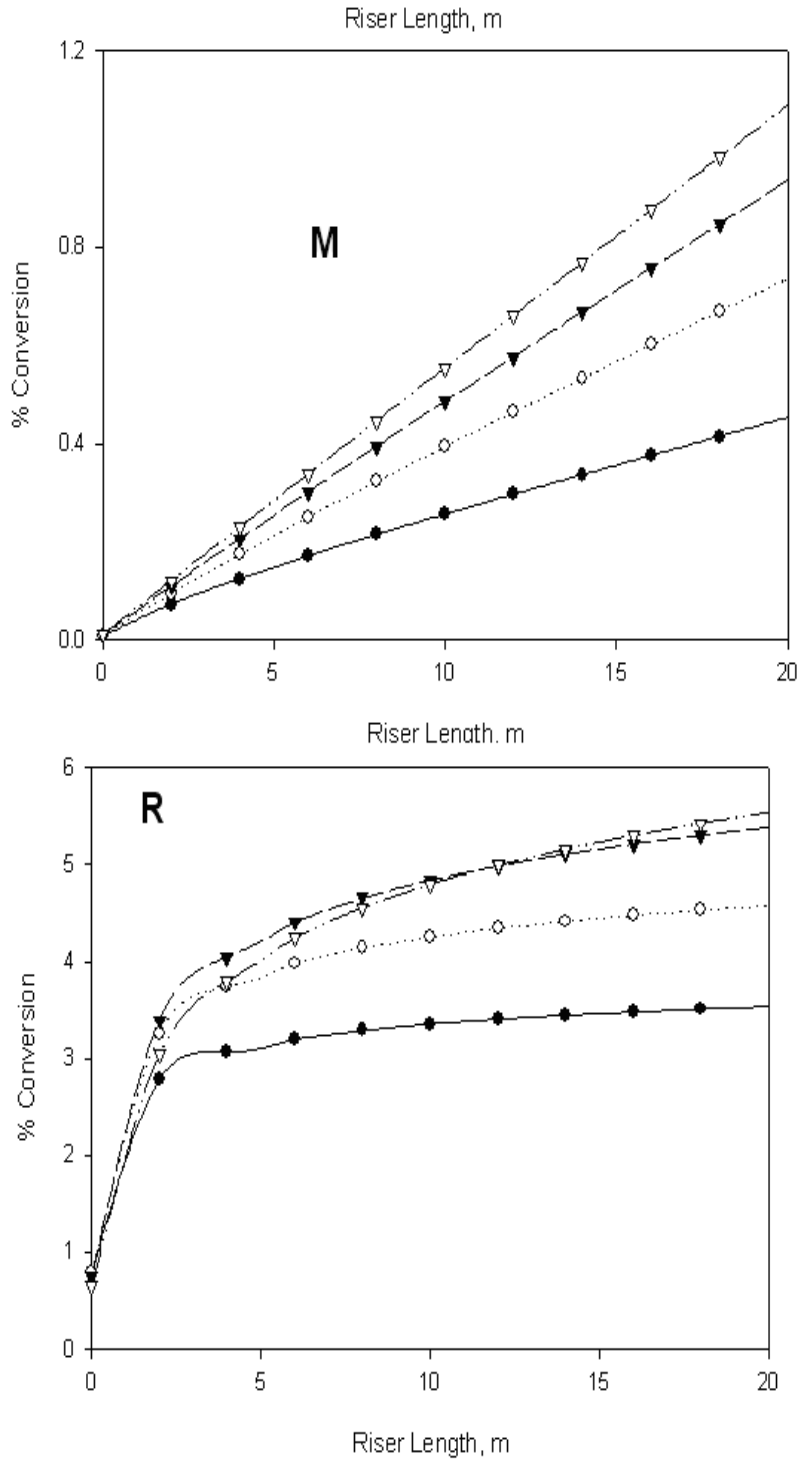

Figure 6. Effect of solid circulation rate on propane conversion
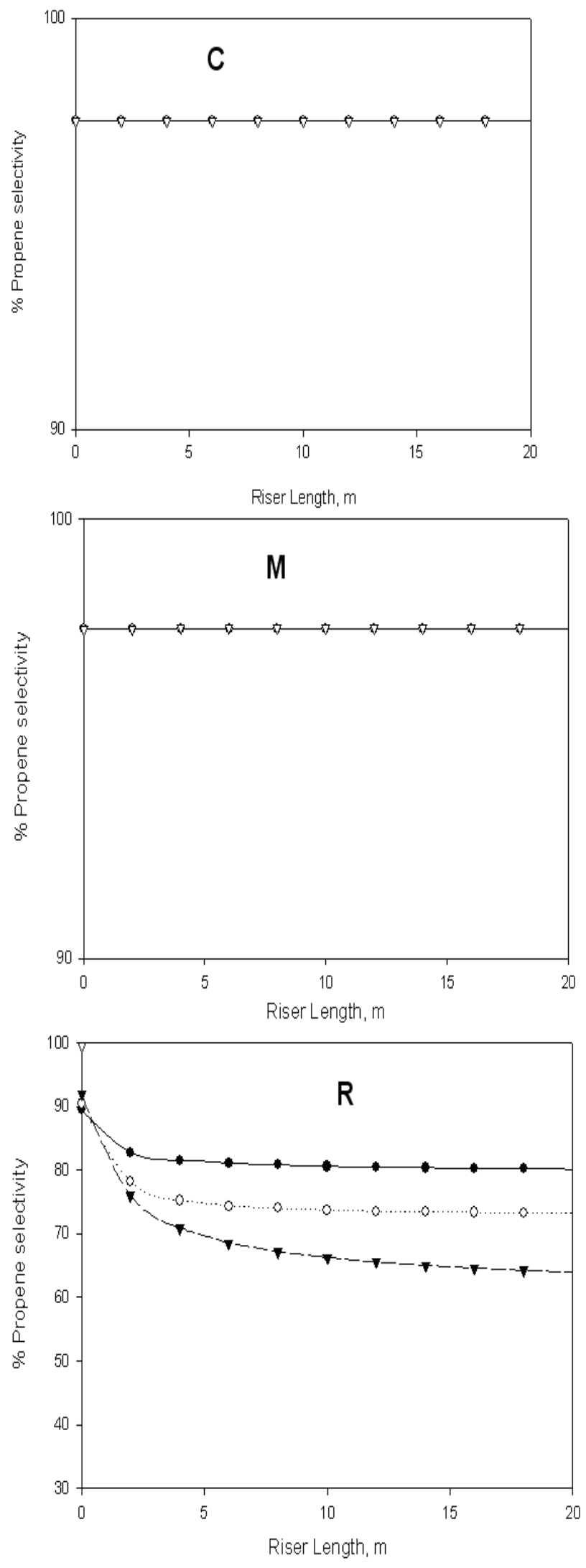

Figure 7. Effect of solid circulation rate on propylene selectivity 
The Journal of Engineering Research Vol.3, No. 1 (2006) 19-30
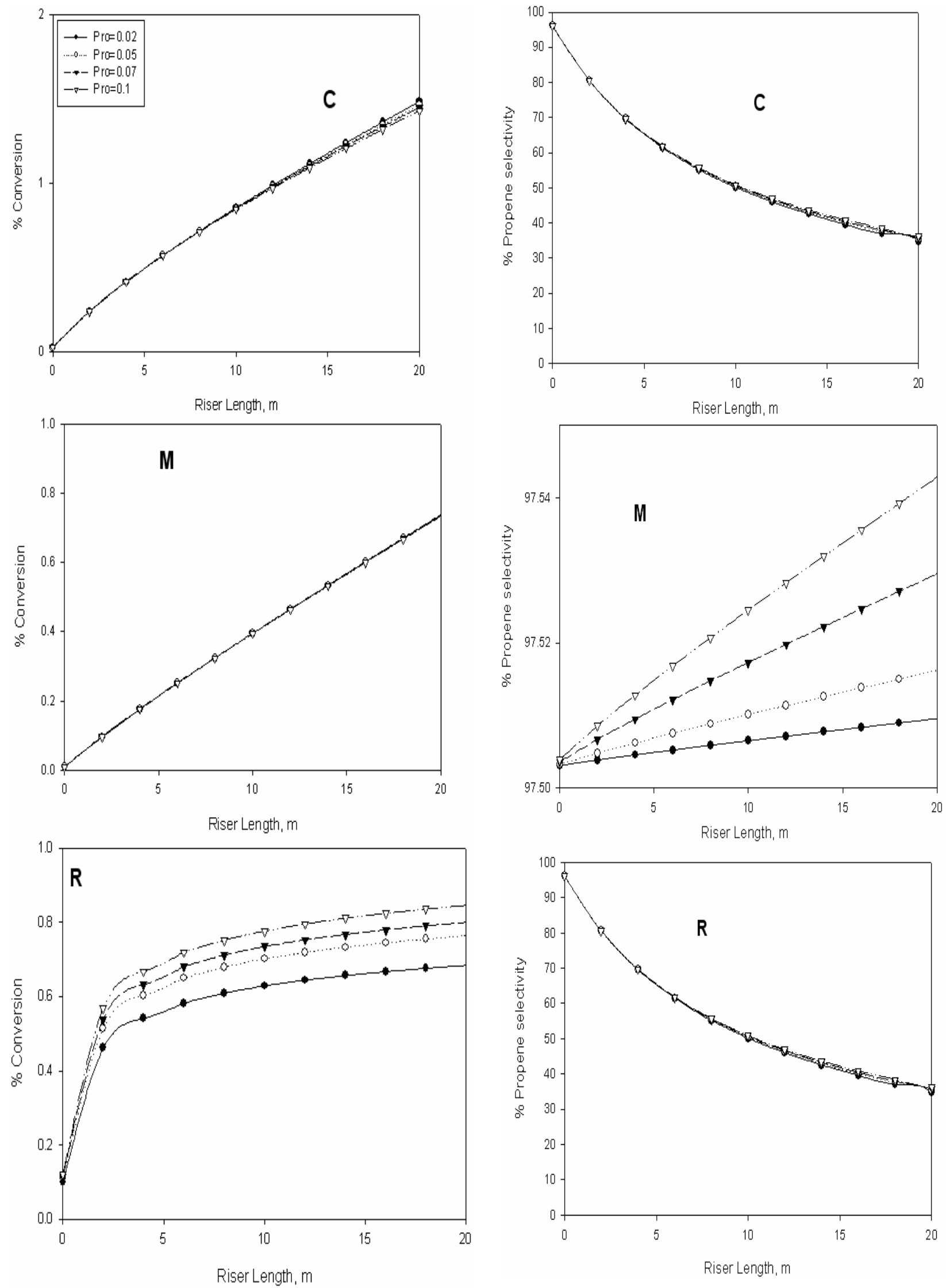

Figure 8. Effect of propane concentration on propane conversion

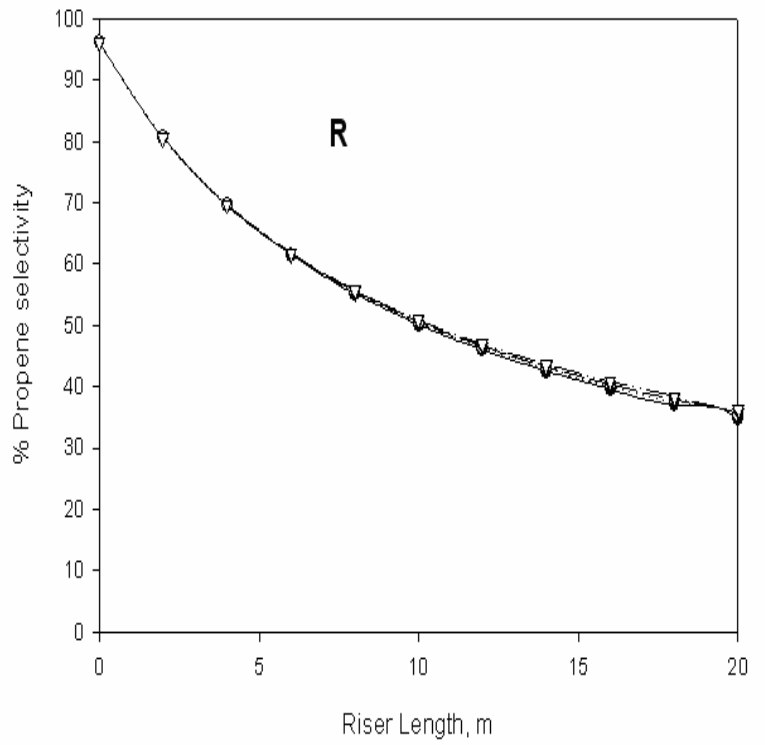

Figure 9. Effect of propane concentration on propylene selectivity 
The Journal of Engineering Research Vol.3, No. 1 (2006) 19-30
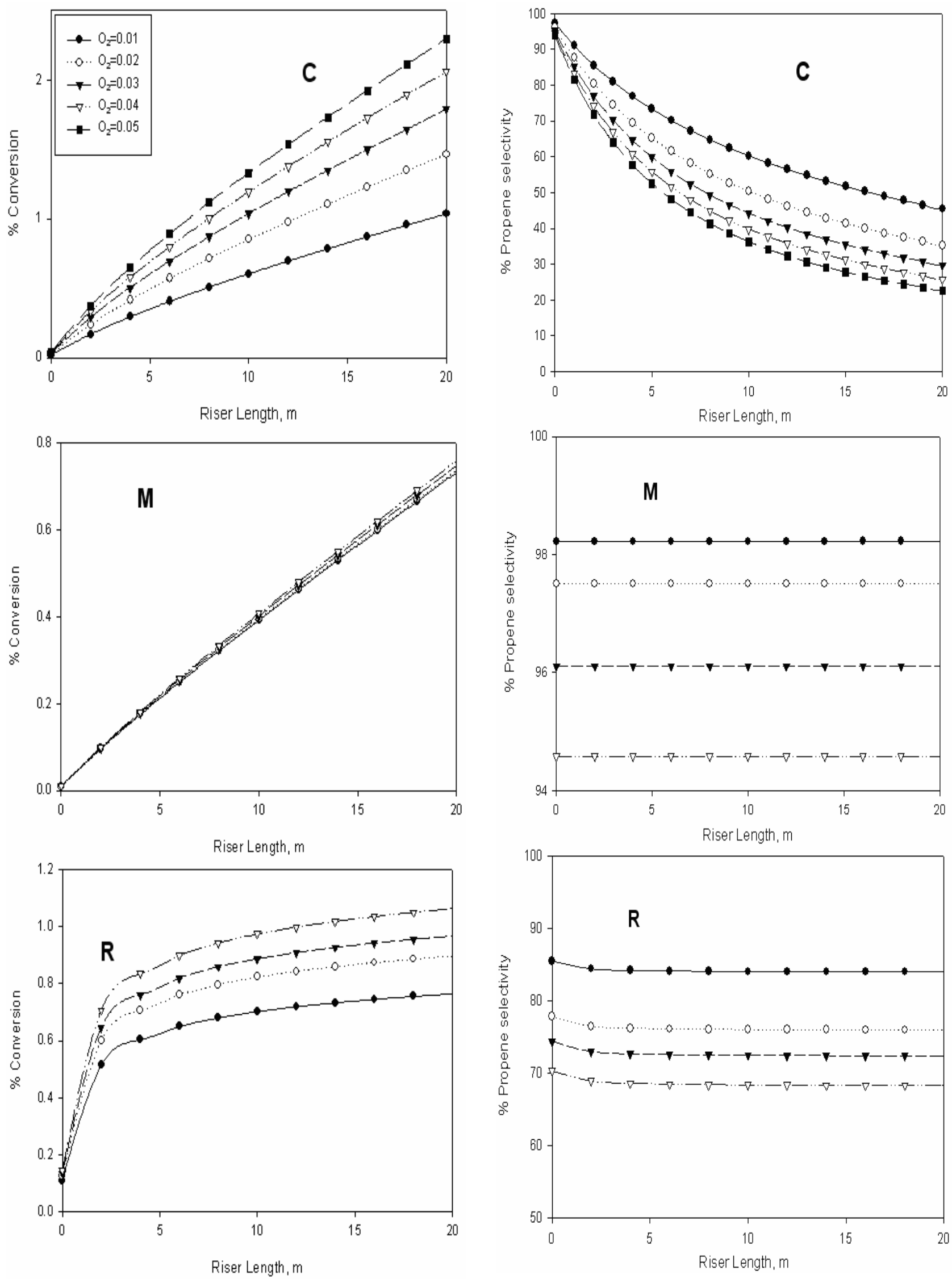

Figure 10. Effect of oxygen concentration on propane conversion

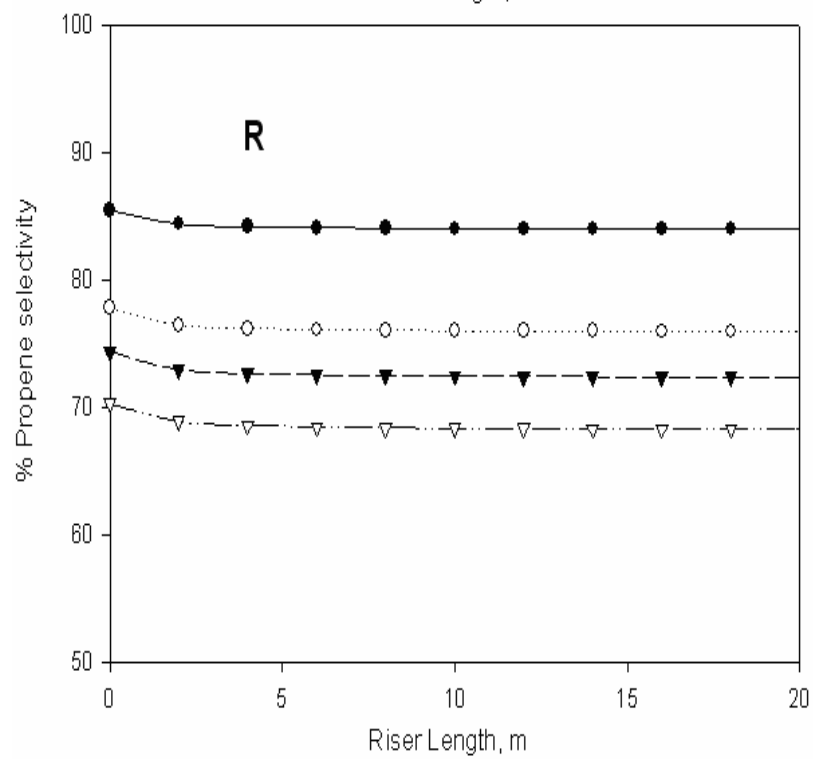

Figure 11. Effect of oxygen concentration on propylene selectivity 
The Journal of Engineering Research Vol.3, No. 1 (2006) 19-30
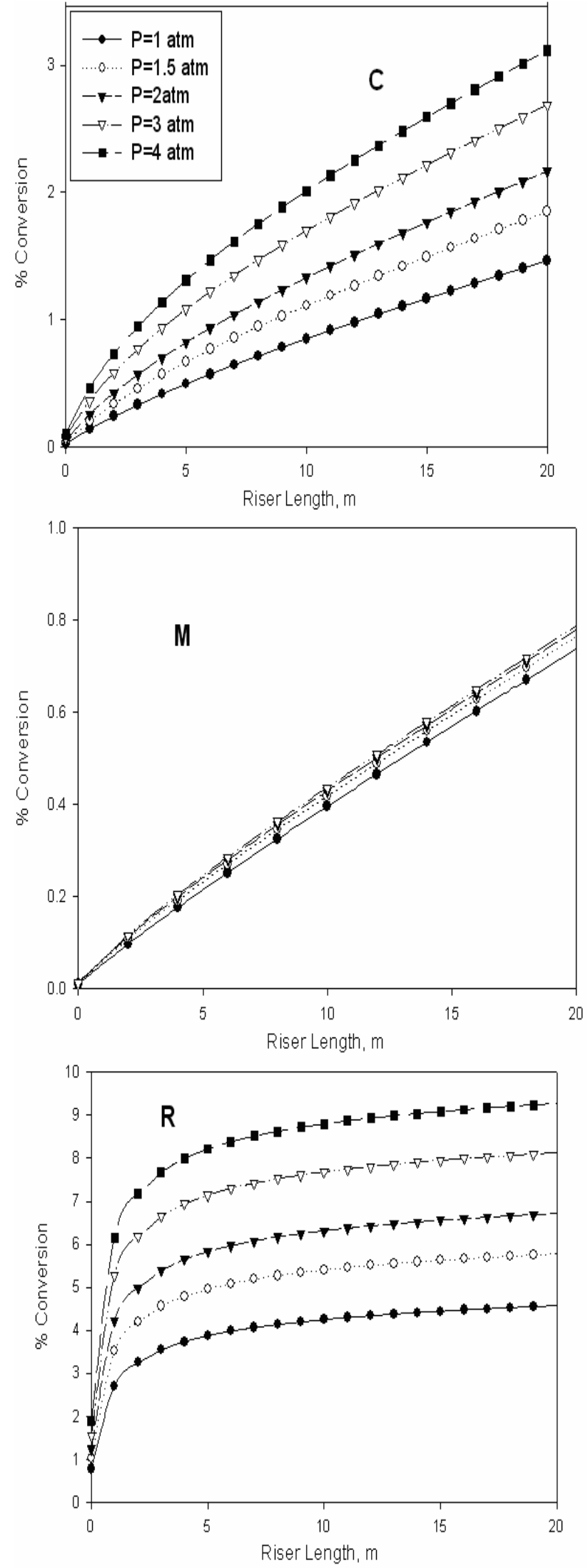

Figure 12. Effect of pressure on propane conversion
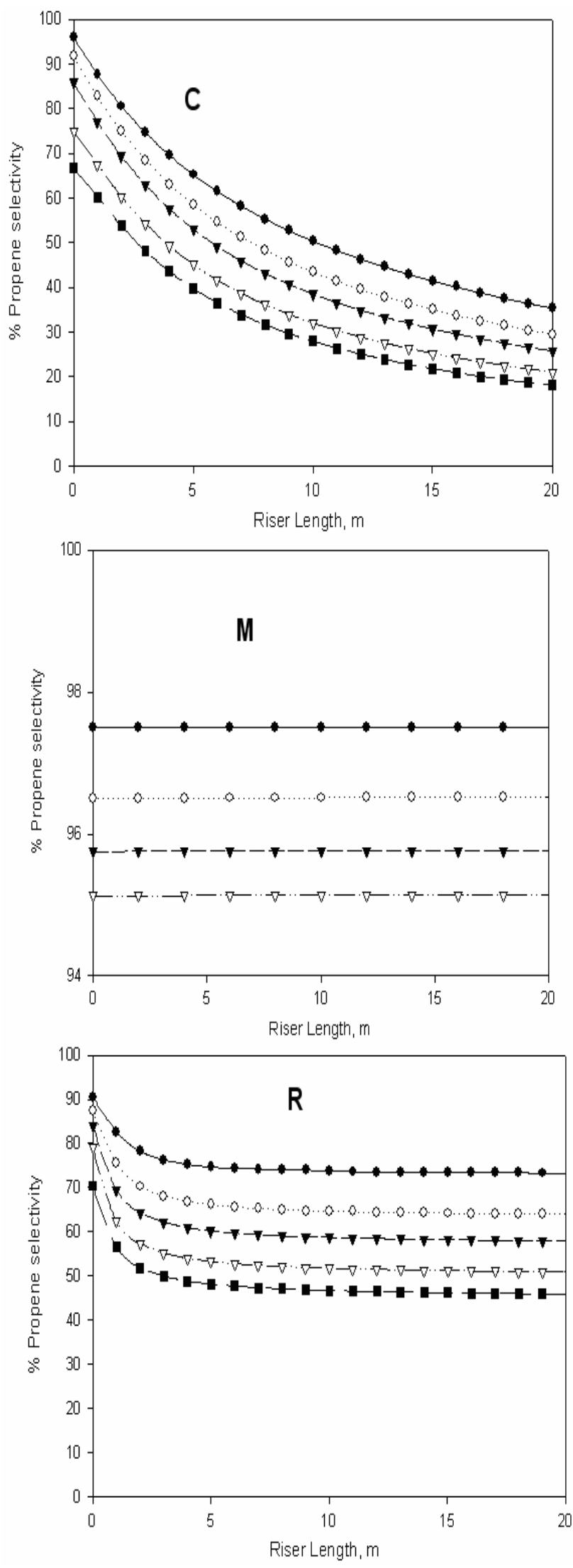

Figure 13. Effect of pressure on propylene selectivity 


\section{Conclusions}

Sensitivity studies of three different catalysts for oxidative dehydrogenation of propane to propylene were carried out using a circulating fluidized bed reactor. The following conclusions are made. Increasing temperature, solid circulation rate, and pressure, and decreasing the gas velocity increase the conversion. However, the catalysts studied behave differently with respect to selectivity. R catalyst is, in general, superior in terms of yield with respect to the other catalyst although its selectivity towards propylene formation is not the best.

\section{References}

Barsan, M.M. and Thyrion, F.C., 2003, "Kinetic Study of Oxidative Dehydrogenation of Propane Over Ni-Co, Olybdate Catalyst," Catal. Today., Vol. 81, p. 159.

Berruti, F. and Kalogerakis, N., 1989, "Modeling the Internal Flow Structure of Circulating Fluidized Beds," Can. J. Chem. Eng., Vol. 67, p. 1010.

Chen, K., Bell, A.T. and Iglesia, E., 2000, "Kinetics and Mechanism of Oxidative Dehydrogenation of Propane on Vanadium, Molybdenum, and Tungsten Oxides ," J. Phys. Chem. B., Vol. 104, p. 1292.

Creaser, D. and Andersson, B.O., 1996, "Oxidative Dehydrogenation of Propane Over V-Mg-O: Kinetic Investigation by Nonlinear Regression Analysis," Appl. Catal. A: General., Vol. 141, p. 131.

Creaser, D.C., Andersson, B., Hudgins, R.R. and Silveston, P.L., 2000, "Kinetic Modeling of Oxygen Dependence in Oxidative Dehydrogenation of Propane," Canadian J. of Chem. Eng., Vol. 78, p. 183.

Fakeeha, A.H., Soliman, M.A. and Ibrahim, A.A., 2001, "Comparison between VPO Catalysts for Production of Maleic Anhydride from Butane in a Circulating Fluidized Bed," Afinidad LVIII., Vol. 494, p. 261.

Fakeeha, A.H., Soliman, M.A. and Ibrahim, A.A., 2000, "Modeling of a Circulating Fluidized Bed for Ammoxidation of Propane to Acrylonitrile," Chem. Eng. and Proc., Vol. 39, p. 161.

Gianetto, A., Pagliolico, S., Rovero, G. and Ruggeri, B., 1990, "Theoretical and Practical Aspects of Circulating Fluidized Bed Catalytic Reactions (CFBRS) for Complex Chemical Systems," Chem. Eng. Sci., Vol. 45, p. 2219.
Goibig, K.G. and Werther, J., 1997, "Selective Synthesis of Maleic Anhydride by Spatial Separation of nButane Oxidation and Catalyst Reoxidation," Chem. Eng. Sci., Vol. 52, p. 583.

Grabowski, R., Sloczynnski, J. and Grzesik, N.M., 2003, "Kinetics of Oxidative Dehydrogenation of Propane over V2O5/TiO2 Catalyst", Appl. Catal. A: General., Vol. 242, p. 297.

Michaels, N.J., Stern, D.L. and Grasselli, R.K., 1996, "Oxydehydrogenation of Propane Over Mg-V-SbOxide Catalyst. II Reaction Kinetics and Mechanism," Catalysis Letters, Vol. 47, p. 139.

Pannek, U. and Mleczko, L., 1998, "Reaction Engineering Simulation of Oxidative Coupling of Methane in a Circulating Fluidized Bed Reactor," Chem. Eng. Technol., Vol. 21, p. 10.

Patience, G.S. and Mills, P.L., 1994, "Modeling of Propylene Oxidation in a Circulating Fluidized Bed Reactor," in: V.C. Corberan, S.V. Bellon (Eds.), New Developments in Selective Oxidation II, Elsevier, New York, p. 1.

Pugsley T.S. and Berruti, F., 1996, "The Circulating Fluidized Bed Catalytic Reactor Model Validation and Simulation of the Oxidative Coupling of Methane," Chem. Eng. Sci., Vol. 51, p. 2751.

Pugsley, T.S. and Malcus, S., 1997, "Partial Oxidation of Methane in a Circulating Fluidized Bed Catalytic Reactor," Ind. Eng. Chem. Res., Vol. 36, p. 4571.

Pugsley, T.S., Patience, S.G., Berruti, F. and Chaoki, J., 1992, "Modeling the Catalytic Oxidation of n-Butane to Maleic Anhydride in Circulating Fluidized Bed Reactor," Ind. Eng. Chem. Res., Vol. 31, p. 2652.

Ramos, R., Pina, M.P., Menendez, M., Santamaria, J. and Patience, G.S., 2001, "Oxidative Dehydrogenation of Propane to Propene, 1: Kinetic Study on V/Mg," Canadian J. of Chem. Eng., Vol. 79, p. 891.

Ramos, R., Pina, M.P., Menendez, M., Santamaria, J. and Patience, G.S., 2001, "Oxidative Dehydrogenation of Propane to Propene, 2: Simulation of a Commercial Inert Membrane Reactor Immersed in a Fluidized Bed," Canadian J. of Chem. Eng., Vol. 79, p. 902.

Wong, R., Pugsley, T. and Berruti, F., 1992 "Modeling the Axial Voidage Profile and Flow Structure in the Riser of Circulating Fluidized Beds," Chem. Eng. Sci., Vol. 47(9-11), p. 2301. 